\title{
Paradise Lost: Difference between Adam and Eve's Lament on Leaving Paradise - A Contrastive Analysis ${ }^{1}$
}

\author{
Sara Torres Servín \\ Hankuk University of Foreign Studies, 89 Wangsan-ri, Mohyeon-myeon, Cheoin-gu, Yongin-si, Gyeonggi-do, 449-791, \\ SOUTH KOREA \\ e-mail: sara_torres1@hotmail.com
}

\begin{abstract}
The difference between Adam and Eve's lament on leaving Paradise in Milton's Paradise Lost is striking in its contrastive content and depth. This paper analyzes the difference that exists between the feelings and spiritual attitudes that Adam and Eve express on the occasion when they are informed by the angel Michael that they have to abandon the Garden of Eden. It is a comparison of their lament in order to understand the contrast of the two attitudes that Milton wove in the tapestry that Paradise Lost is. The paper also explores male and female roles in Paradise Lost and concludes that Adam and Eve are equal yet different, that difference being the cause of their contrastive ways of expressing their sorrow. Adam and Eve manifest two contrastive worldviews in opposition, one spiritual (heavenly), and the other material (earthly).
\end{abstract}

Keywords: Difference, lament, regret, sorrow, material worldview, spiritual worldview

\section{INTRODUCTION}

Much of the theology presented in Paradise Lost is purely Miltonic, that is to say, Milton drawing on his own beliefs and understanding of the Christian truth to narrate his epic. He had the ground for doing so for he was a committed Puritan, read Scripture in the original languages and in Latin, and studied it on a regular basis. His Psalms translations from Hebrew, for instance, are recognized as fine literary works. Paradise Lost is then quite peculiar in the way Milton developed much of his own theology. In regards to this, Knott (2005) says that "perhaps what made Milton's epic definitive was a system of religious definitions written by Milton himself' (p. 66).

Thus, in his personal theological perception, Milton confers upon Adam and Eve personal characteristics, traits, and ways of comprehending reality and behaving in a manner that he believed was right for his times. His worldview was based on the cultural reference of his seventeenth century England. So from that platform, he assigns the couple in the Garden of Eden some specific tasks that they realize as part of their daily life. These activities bring meaning and purpose to their life in an oriented way,

\footnotetext{
${ }^{1}$ This work was supported by the Hankuk University of Foreign Studies Research Fund of 2013.
}

since it even gives them a reference of cyclical order with the rolling of the seasons and the succession of day and night. From that standpoint even rest takes on a different dimension and special meaning for the couple, as a projection from the work they do in Paradise.

\section{ANALYSIS}

Adam and Eve engage in gardening activities, and Milton ascribes Eve the special role of master gardener. In this ecological role, Hiltner (2003) sees Eve as "the genius of the Garden," for he considers that "the place is of profound environmental importance" (p. 5). Eve seems to be more sensitive than Adam to the flowers, which she names and tends with nurturing care. She even seems to have her favorite garden spots, according to Knott (2005). This gardening activity - the care of tilling, planting, pruning, harvesting, and everything related to the vegetal world - was ordained by God, hence its importance, even though it is apparently a simple task. Through this gardening work, Furman-Adams and Tufte (2004) see "the divine government of the natural world" (p. 235).

Knott (2005) also commends their work "for giving rhythm and meaning to their daily lives and for engaging them in an exchange with a vital natural 
world that affirms their harmony with it as well as affording them pleasure" (p. 76). For Strier (2012), Adam and Eve "even learn moral lessons from their environment, from Eden" (p.42). Furman-Adams and Tufte (2004) say that in Paradise, "flowers teach the lesson of patient submission, meek endurance, and innocent cheerfulness under the pressure of adverse circumstances." They point out that "many are the moral precepts they inculcate, bidding us admire the wisdom of their omnipotent Creator, in their infinite variety of forms and colours, and perfect adaptation to the situation they occupy" (p. 234).

As master gardener, Eve seems to spend long hours at her task. Since her gardening takes most of her day, this activity must mean a lot to Eve. She probably gives much, if not all, of herself into the task. Besides, it is in her giving of herself to the task that she develops a bond with her surroundings and a sense of security based on the nature of the routine of her activity. The logical result of such committed dedication is in all certainty the materialized array of a colorful expanse of a variety of exquisite flowers. This must produce a great aesthetic pleasure and bring great joy to Eve, the kind of joy that fills the soul in a deep significant way.

On the other hand, while Eve tends the garden, Adam engages in regular conversation with God. Adam and the Creator speak as friends, and their conversations are most surely based on his daily activities, his work, his relationship with Eve, and everything that is related to him: "On this Mount he appeerd, under this Tree / Stood visible, among these Pines his voice / I heard, here with him at this Fountain talk'd..." (XI, 317-322). In the conversations they have, God speaks to Adam about the Garden of Eden, what he can do and cannot do there, the naming of animals, and they even get to talk about man's solitude. As a man, Adam is the glory of God, and as such, God must find great pleasure in interacting with His creation, listening to him, speaking to him, instructing him on necessary matters, educating him towards the fulfillment of His plans. God is Adam's complement. He feels fulfilled in his Creator.

In the same manner in which the flowers are vitally dynamic for Eve in her close relationship with them, God becomes transcendentally important to Adam's experience as a human being. However, he seems to show a clearer sense of the larger purpose of their labor in the garden, since God has made it for delight, according to Knott (2005), but also for reason, to put their intellectual abilities at the service of Paradise: "For not to irksome toile, but to delight / he made us, and delight to Reason joined" (IX, 242-243). It is for delight and reason, not just for feeling, as it is in Eve's case. The intellect is an overall active part of keeping the garden.

Both Adam and Eve work gardening Paradise, but their attitudes and approach to the work are different. All this is clearly seen by the way they react and the words they utter when they are informed by Michael that they are to leave the Garden. In the New Testament, Jesus Christ says "For the mouth speaks what the heart is full of," in Luke 6: 45. Sooner or later what is in the heart will be manifested outwardly. It is what in the end happens with Adam and Eve they express, through words, what they have in store in their hearts. It is a matter of consequence. It is in the heart, it will then come out in due time. The pressure of outside factors triggers the heart to manifest itself at a given moment in the life of a person. Adam and Eve are no different.

\section{EVE'S LAMENT: A MATERIAL WORLDVIEW}

There is no doubt that the Garden of Eden holds rich and special significance for Eve. In time, and due to the nature of her work, she has come to develop a feeling not only of belonging there, but of being a part of the whole setting of Paradise. She has come to understand the meaningfulness of the gardening activity that attaches her strongly to the land, in a codependable way. She draws a deep sense of security and spatial reference from it and enjoys a unique relationship with her work. Therefore to Eve Paradise is a synonym of stability - she is rooted to the land in the same way her plants are rooted to the groundand an external projection of her spiritual sense of aesthetic beauty - her flowers meet her soul's spiritual needs. This feeling of beauty in turn is instrumental in Eve's creativity in the care of her flowers and their arranging in ways that please her aesthetic spirit. Eve thus has a special feeling of attachment to the Garden of Eden. Paradise is home.

Paradise occupies the core of Eve's being only after Adam, the husband and sole companion who means everything to her. Mattison (2007) even believes that Eve suggests that "the relationship between her and Adam depends on their mutual relationship with Eden itself' (p. 96). So through her gardening work Eve has learned to appreciate the bountiful nature that surrounds her with its beauty and succulent fruitfulness. She has grown fond of it and learned to love it. It is as a matter of consequence, being there seeing all the loveliness and loving it in return. Eve feels the emotion of being blessed by her work with the flowers. All of Paradise has become a sacred dwelling place. This is the work of her hands, what 
she has produced, and she feels useful because of what she has accomplished. She has faithfully adapted to the challenges of Paradise and has succeeded. She has tamed it all: "herb, tree, fruit and flour" (IV, 644).

Strier (20012) is of the belief that "Edenic nature is notably un-rule bound" (p. 41), because Eden is "a wilderness of sweets," (V, 294). Hence Eve's only objection to the Garden is that things grow too quickly in Eden, as seen by her words "wanton growth" (IX, 211). However, according to Mattison (2007), "she lives in a garden, and she needs to understand how it is constructed" (p. 82). Hiltner (2003) cites Mc Colley saying that "Milton's Eve is different from all other Eves by the fact that she does her work seriously," as Milton's Garden is "a real garden really needing care" (p. 53). Thus Strier suggests that Eve seems to have "an aesthetic aversion to the messiness of Eden (IV, 629-631) as well as an intuitive sense of how to intervene usefully in it (V, 212-216)" (p.42). She deeply identifies herself with her garden.

Consequently, when Eve is suddenly faced with the divine order to leave her blessed garden, it does not come as a surprise that she opens up her heart to express her deep-rooted emotions "with audible lament" (XI, 265). Eve pours her soul exposing the depth of her attachment to her flower garden. However, one can sympathize with Eve's reaction and still recognize a form of excess and a failure to grasp the fundamental significance for the loss of Paradise. According to Knott (2005), Eve's response focuses first on her flowers' presumed need of her nurturing and also on an environment in which she feels at home, in part because of her efforts to domesticate it (p. 80). However, again, this is Eve's universe, second only to Adam. There is nothing else besides this for her. For that reason she cries out in anguish to lament her imminent loss:

O unexpected stroke, worse then of Death!

Must I thus leave thee Paradise? thus leave

Thee Native Soile, these happie Walks and Shades,

Fit haunt of Gods? where I had hope to spend,

Quiet though sad, the respit of that day

That must be mortal to us both. $\mathrm{O}$ flours,

That never will in other Climate grow,

My early visitation, and my last

At Eev'n, which I bred up with tender hand

From the first op'ning bud, and gave ye Names,

Who now shall reare ye to the Sun, or ranke

Your Tribes, and water from th' ambrosial

Fount?

Thee lastly nuptial Bowre, by mee adornd
With what to sight or smell was sweet; from thee How shall I part, and whither wander down Into a lower World, to this obscure And wilde, how shall we breath in other Aire Less pure, accustomd to immortal Fruits? (XI, 268-285)

This is a sorrowful lament that comes from the depths of Eve's inner being. It embodies precisely what Eve experiences about having to leave her home forever. She voices significant questions that reveal how transcendentally important her settled, secure, and predictable life in Paradise has become for her. Whereas Adam utters one question only, Eve's enunciation of eight is a notable and worthy indication of the intricacies of the female soul, differing from that of man. Paradise becomes for Eve a matter of material survival — what will become of her flowers without her care? This is a mystery to Eve. Since there are no other people in Paradise, then there is nobody who will become responsible for her flowers. A careful reading of Eve's lament reveals a chain of mental and spiritual realities that assist us in seeing what lies behind the words she speaks and what the extent of her anguish is at having to leave her plants and flowers behind in order to go to an unknown inhospitable world. The lament Eve cries out is expressed by rhetorical questions that are the centripetal force having her as the focal center. First, she addresses Paradise itself, the land that is her homeland, her native soil, with two questions. The first question is uttered in the following manner

"O unexpected stroke, worse then of Death! /

\section{Must I thus leave thee \\ Paradise?"}

Leaving Paradise has the quality of being worse than death itself for Eve, even though she has no experiential knowledge of it. She certainly knew that if she and Adam ever disobeyed God's command not to eat the fruit of the Tree of Life they would not only die but be expelled from Paradise as well, which is the case at the moment. Eve is then completely aware of the consequences of her transgression - she has to leave Paradise now and one day she will surely die physically. God's words were clear when He uttered His design concerning their possible disobedience.

The day thou eat'st thereof, my sole command

Transgrest, inevitably thou shalt dye;

From that day mortal, and this happie State

Shalt loose, expell'd from hence into a World

Of woe and sorrow. [VIII, 329-333]

So the question now of "Must I thus leave thee Paradise?" is somewhat futile. Even though Eve knew she would eventually have to leave Paradise if 
she ever disobeyed, she still dares voice her question, which by modern standards would read something like Do I then have to leave you, Paradise? Behind these words there seems to loom a Why? Why me? Is this not my home then? If leaving Paradise is worse than death, then there is nothing left to be said. What can be worse than the finality of death for a human being? Yet Eve senses the loss of her Paradise as worse than that. This speaks very highly of what Eden means to her. She sees no more than "a World of woe and sorrow" (332-333) outside of Paradise.

Afterwards Eve proceeds to put into words her second question:

...thus leave / Thee Native Soile, these happie

Walks and Shades, / Fit haunt of Gods?

If Eve's first cry was for Paradise itself, the parting of her natural habitat, now the second is for her Native Soil. From the more general realm of the wholeness of the place Eve now narrows down the concept of the general to the more specific. Now it is about her native soil, the place where she was born -or rather where she came into being. The word native refers to birth or being born; it speaks of the first reference of locality for a new-born. To Eve, her native soil conveys a sense of belonging, of being identified with "these happie Walks and Shades" (XI, 270), because she has spent significant and valuable time in it and has experienced happiness in its midst. The Native Soil is her first reference to the existing physical world.

Eve acknowledges Paradise as her native country. Under this assumption, her loyalty is to the land where she has come to be a living soul, to learn to love her work and the product of her work, and to identify with the surroundings. In the final analysis, Paradise is the only reference of location Eve possesses. Her native land is a place that is "fit haunt of Gods" (XI, 271). More than that, Eve says that her Native Soile is the place "where I had hope to spend, / Quiet though sad, the respit of that day / That must be mortal to us both" (XII, 271-273). As her native country, it is Eve's hope to be on Paradise while she and Adam expect their death, as the penalty for their transgression.

The first logical conclusion here is that her native soil is then of transcending importance to Eve. It goes much deeper than being a place of mere happiness or the cultivation of the land or for enjoying the contact with her lovely flowers. It is the place where she wants to die on the day when she and Adam will have to leave this world. The question that she asks is of foundational value. There is no place for her other than the Paradise where she first came to know herself. How, then, can she ever leave it? It is preposterous to even consider the possibility of being outside of the blessing forever. How can she even die far from it?

Secondly, Eve addresses her flowers, and speaks to them as if they were living entities with understanding. She asks her questions using the pronoun "who" three times with three different verbs. A question that has the pronoun "who" as its subject demands a human person as its answer.

"O flours, / That never will in other Climate grow, / My early visitation, and my

last / At Eev'n, which I bred up with tender hand / From the first op'ning bud, and gave ye Names, / Who now shall reare ye to the Sun...

Summers recognizes in expressions such as "bred up" and "rear ye" "the lament of a mother for her children - and that the children as yet are only flowers" ( $p$. 189). Eve anthropomorphizes her flowers, and is sincere in her concern for their wellbeing. Nicolson (1963) points out that these flowers are Eve's own and that she has given them their names, in the way that Adam has given names to the animals of Paradise (p. 307). Hence the closeness she feels with the flowers, as if they were her own children. Nicolson also sees Eve as "a symbol of the true-born English woman to whom her garden is her spiritual home" ( $p$. 307). That spiritual home speaks of a strong bond between Eve and her Garden.

Moreover, a very important aspect of Eve's relationship with her flowers is the time that she has spent with them. She has invested much time in the care of her garden. As a result, she has developed a deep and meaningful relationship with her flowers. As their caregiver, she is entitled to feel the way she does about those flowers. They are like her children to her. She feels responsible for them because she cares for them. That is all she knows and it is enough for her. Her personal universe moves around the flowers that occupy her days.

Keeping the same topic of who will care for her flowers the way she does, Eve now moves on to a more scientific level to voice her question:

...or [who now shall] ranke Your Tribes...

She asks of who will make the effort, the way she has done, to rank the flowers. Flannagan (1998) points out that "Eve pictures herself not only naming the flowers but establishing a classification system according to something like a hierarchical series of genus and species" (p. 668). This speaks of no simple 
work but rather complex and organized. Consequently, Eve cannot think of anyone who will take the pain to do what she has done. The way she thinks and her attitude posit a disquieting reflection: Did she never think of God? Did she not think that He could be the sufficient answer to her painful questions? There is no evidence to the contrary.

Finally, Eve voices her last question to the flowers and this time she mentions the act of watering them, a key element that is a matter of survival for the plants and flowers.

\section{... and [who now shall] water from th'} ambrosial Fount?

As all previous questions, Eve asks who will possibly water her flowers and plants the way she has done for so long. Flannagan (1998) concurs that "the Fountain of Life in Paradise was supposed to run nectar" (p. 668) from the ambrosial Fount. This made Eve's work and the special nature of the task a transcending activity. From this it can be inferred that if the flowers were like her own children to Eve, then the process of watering them for their survival and development is the equivalent of her breastfeeding them, nurturing them with her own nectar. In the same way that a baby would die without being fed by its mother, so would Eve's flowers without her watering.

The last portion of Eve's lament is now directed to her matrimonial site of rest, her bower, where she would spend special moments with her lover Adam.

Thee lastly nuptial Bowre, by mee adornd /

With what to sight or smell was

sweet; from thee / How shall I part. . .

In the opinion of Summers (1966), "Eve identifies her human love with the place rather than with her lover" (p. 189). There is not even a hint or reference to the one who would share the spot with her. Her focus is not the object of her love and physical passion. She seems to care far more for the actual physical characteristics of the place of rest and the way she would look after it. This is also an extension of her task of minding the garden. Eve has devoted time to decorate and keep her bower pretty and smelling nice. That is about it with the bower. Then she keeps on with her questioning.

\section{... and whither wander down / Into a lower}

World, to this obscure / And wilde...

Eve keeps exteriorizing her lament on having to leave paradise. This time she asks in which direction she will go into the world which is lower than the one she inhabits now. She of course has the reference God Himself had given them in the past concerning their fate outside of Paradise, that they would be "expell'd from hence into a World / Of woe and sorrow" (VIII, 333). However, she cannot fathom how she can just leave her Paradise and step into this desolate new world. She has no sense of direction, an interesting feminine trait shared by many of her sex. She cannot imagine the lower world as a physical space. She has no reference and does not know where to go in the world outside of Paradise.

The last question of the lament being uttered comes as a revelation, given the tenor of the previous seven.

...how shall we breath in other Aire

Less pure, accustomd to immortal Fruits?

Only now, as a final way of bringing it all together, at the end of her lamentation, Eve includes Adam in her cry of anguish, with the pronoun "we" and in regards to breathing less pure air! So Adam is not part of her private kingdom of aesthetic loveliness constituted by her flowers. In Platonic terms, Miller (1978) sees Eve as "all that pulls the soul earthward" (p. 110). She belongs with her plants and flowers on the earth, whereas Adam "aspires to heaven." Interestingly, in the Korean cultural and philosophical tradition men are also characterized as belonging to heaven and are thus represented by the color blue, whereas women belong to the earth and are represented by the color red.

Eve's lament concludes with this final cry of sorrow at having to leave Paradise. It is a lengthy lament, a pouring of the heart before her imminent expulsion from the place she knows as her only home. The lament is characterized by her personal selfabsorption. She sees herself as the center of the great loss. This is a lament for the native land, a lament for the flowers of the land, and a lament for a place of rest in the land, her land. With the words she utters Eve reveals what her heart is full of - only the things she cares about, no more. Interestingly, she never mentions God in her lament, or invokes His name. He being the Creator of it all, why does she not see Him as part of the whole? This is more like the disintegration of her own personal world, not even Adam's.

Technically speaking, Eve's lament is articulated by means of eight rhetorical questions. She cries out her "who's" and "how's" and "whither." Suggestively, she begins her questioning with the personal "who." In addition, other than herself, there is no answer to that questioning, since not even God is contemplated as a possible answer. Then comes the "how" to indicate the manner of action. It is only in this instance that she includes Adam in her lament. 
"Whither" also refers just to herself as having no sense of direction. So out of eight, seven questions refer just to her. In light of this, the words of Jesus, as expressed in Luke 6:45 come to mind: "The mouth speaks what the heart is full of." Eve is thus more oriented to herself. She possesses an inward vision of reality that transcends outwardly. Her flowers are a projection of this inward reality. They belong in the land and to the land, as she feels she belongs there as well. She is part of the land, the ground, the earth.

\section{ADAM'S LAMENT: A SPIRITUAL WORLDVIEW}

In the order of creation, Adam, as the first living soul created, is the glory of God. As a being created in the image and likeness of God, he is endowed with pure reason and intellect, that is, cognitive abilities, and an intelligence that is dynamic and creative at the same time. In contrast to the aesthetic type of work that Eves does, the work that Adam realizes in Paradise gives orientation and purpose to his daily life. The important element, however, and the attraction that Paradise holds for him is the direct contact he has with his Creator and the enjoyment he derives from that close contact.

The personal contact with God and his dependence on Him are relevant to Adam. The closeness and intimacy he experiences with his Creator fills his life. This kind of deep meaningful relationship is the same Eve experiences with her flowers. This fact points to a different set of priorities for both Adam and Eve. For Adam it is a spiritual reality, whereas for Eve it is the realm of the earthly. For Adam heaven is his spiritual home, for Eve, on the other hand, it is her garden. If their heart orientation goes in opposite directions, we see here two opposing self-contained worldviews.

In the same way that Eve has learned to love her flowers that are the final product of her tender care and dedicated labor, Adam has also learned to trust in this Creator who has shown so much love and consideration in creating him and then creating a help mate for him. Adam never has reasons to doubt God or to feel displeased about something that comes from Him. Consequently, in this instance, it is only natural that when the crucial moment comes to abandon Paradise, the home given to them as a present from their Maker, Adam should voice his lament to bring forth the voice of his heart. It is a voice that expresses what truly lies deep within.

Paradise is a safe place for Adam. It gives him the stability and security he needs to be a normal human being. So when the Angel Michael informs him that he and Eve are to leave it, Adam reacts audibly. He utters words of grief to communicate his emotion:

"This most afflicts me, that departing hence, / As from his face I shall be hid,

deprivd / His blessed count'nance..." (XI, 315317).

This is the uppermost concern in Adam's mind, what afflicts his soul—knowing that he will not see God anymore. So he verbalizes his affliction first, and then brings forth his question. What comes out is what abounds in his heart. Adam is bringing forth what he has sown in his heart before.

Adam's reaction to the angel's news differs qualitatively and quantitatively from that of Eve. After they sin, he immediately thinks of prayer, that is, of praying to God in case $\mathrm{He}$ might change His design towards them. He says that he would cry to God unceasingly, given the enormity of their transgression. Nevertheless, Adam knows that God's holiness will not allow sin in His presence. That is why he decides and declares, "Therefore to his great bidding I submit" (XI, 314). He is humble to the point of surrendering to the divine resolution because he knows the distinguishing moral absolute qualities of the God that has sustained him until now. He knows his Creator, and based on this knowledge he now submits humbly.

Adam then proceeds to state the real motive of his lament on having to leave Paradise, "This most afflicts me, that departing hence, / As from his face I shall be hid, deprivd / His blessed count'nance" (XI, 315-317). For Adam, then, in the perspective from which he sees his future life, leaving Paradise will more than anything mean the separation of God's presence - and of God Himself. Before the Fall Adam lived an altogether different reality. Now when he is about to abandon Paradise, the place that confers him his identity and purpose and influence, the weight of reality sinks in. Adam's attitude displayed at this moment provides some clues as to what the yearning of his soul will be once outside of Paradise and forever separated from God.

The closeness and companionship that Adam has experienced with God in Paradise is what has actually molded his character and made him into the person he is. He has not only been created by God, but formed by Him. He has been given an identity that defines him; an income that is the retribution to his work, and influence to rule in Paradise. Despite all this Adam finds himself confused, emotionally disturbed, and probably not knowing what to do next in such a 
traumatic moment. What he does is to bring to mind what he had experienced with God in the past: the places where they would meet, his worship of Him, "On this Mount he appeerd, under this Tree / Stood visible, among these Pines his voice / I heard, here with him at this Fountain talk'd" (XI. 320-322). He even considers the idea of setting up altars to adore God, as an extension of the fervor he professes Him. God has left His mark in Adam's heart in ways that are unique to how He has made him into a human being.

Therefore, in the midst of his sorrow Adam's deep lament reveals itself through but one question. This only question must have reverberated in Paradise: Where? This suggestive word speaks of locality, vicinity, a place. Where? With this question we are placed in the realm of space, and by extension, a physical place, not just a mental reality or a metaphorical location. It is a Where? which evokes closeness and intimacy for Adam, a place where he could actually feel and enjoy God's presence and companionship. This is the place where he has learned to know and love his Creator. In his attrition he can only express all the feelings that might be combusting deep within his soul with the simple question:

\section{In yonder nether World where shall I seek / His} bright appearances...

This is an existential question for Adam. Where will he ever be able to find God once outside of Paradise? The question is not whether he would find God, but where, where besides Paradise? He cannot probably fathom what it would be like to be at a place other than Paradise. This is his home. This is all he knows. Besides, will God be outside of Paradise? He seems to doubt it. In the same way that Eve never considers God as a possible answer to the care of her flowers, Adam does not seem to consider that God could be anywhere outside of Paradise. That is why the question he utters carries with it such deep tones of despair and hopelessness.

A fact that makes it all the more transcending is the fact that Adam does utter his question. He does not keep it to himself but brings it out as a naked expression of his anguish. Ainsworth (2008) points out that "it is Adam's internal state which prevents him from seeing God's presence in the world," and that "once outside of Paradise, Adam must learn to interpret the world spiritually so that he discover within himself the hand of God, working to redeem him from his sins" (p. 103). The separation from his Maker means finality to Adam. It is hard for him to take such a bitter cup.
Interestingly, however, in contrast to Eve's eight questions Adam voices only one. Adam is the cerebral and intellectual being that has been given so many mental and cognitive abilities by the Creator in order to meet the many needs of Paradise. He has been successful in accomplishing much. And yet, the intellectual person asks only one question. It seems as if Adam comes closer to seeing the significance of the loss of Eden than Eve does. He is explicit in regards to the places where he talked with God before the Fall. So it is a physical presence for him once again. God was there for him. That is all that matters to him at the moment. However, what about the future? What will life be without God outside of Paradise?

The loss of the presence of God, and by extension of God Himself, speaks louder than any other reason to Adam. That is why his sense of loss is so out of proportion and weighs so heavily on him. Adam must have intuited that life without God outside of Paradise would be empty, meaningless, and hopeless. Since locality is fundamental for Adam - God for him in Paradise - now his sense of dislocation is overwhelming and too hard to handle. Thus his reaction expressed in sorrowful lament comes as no surprise. It is only logical to be expected. Adam's is a spiritual reason, so different from Eve's, who sees in material objects her security and hope.

\section{... or [Where shall I his]... footstep trace?}

Adam's Where? now concerns finding God by tracing His footsteps. The first part of his cry deals with where he can seek his Creator, and the answer looming seems to be an ominous "nowhere." Now the second part of his question has to do with the physical evidence of God's presence. How can Adam trace God's footsteps? How can he, in a world that he does not know, where he has never been before? In Paradise he knew exactly where God would be. He was always a close companion. Now in the obscure world he is to inhabit, where will he find evidence of his Creator's presence by tracing His footsteps, if he could even do that?

All these characteristics are the foundation for Adam to be God-oriented in the sense that Eve is earthoriented. His is a spiritual dimension and thus he seeks his Creator. He wants to be connected with his source of life. It is from God that he gets his life. For all these reasons he is now in anguish and despair. Where will he find his Creator, his source of life outside of Paradise? Where will he see physical evidence of His presence? Adam's heart is full of the presence of God, so accordingly, his spoken lament is verbalized to reflect only God. As Miller (1978) 
comments, Adam certainly "aspires to heaven" (p. 110 ), while Eve is more earthbound.

\section{CONCLUSION}

It was the intent of this paper to analyze the difference that exists between the feelings and spiritual attitudes that Adam and Eve articulate when faced with the stark reality of having to leave Paradise. The laments of both man and woman have been compared in order to get a glimpse into the significant contrast that Milton developed in his epic. Adam and Eve disobeyed God so the discipline that they were cognizant of fell heavily upon them. This paper has also explored the male and female roles in the poem. Adam and Eve were certainly created in the image and likeness of God but all similarities end there in the reading of the poem.

According to what has been seen in this analysis of Adam and Eve's differing laments, the conclusion reached at is that even though Adam and Eve are equal, they are essentially different. They have very different origins, Adam coming directly from the Creator while Eve comes from the created, the creature. This different outset provides the platform for the contrastive ways in which they express their sorrow lamenting the loss of Paradise. Both man and woman project their lament in the direction in which their own heart guides them to - Eve to her flowers, her land, the earth, and Adam to God, his home, the heavens.

\section{REFERENCES}

Ainsworth, D. (2008). Milton and the spiritual reader. Reading and religion in seventeenthcentury England. New York: Routledge.

Flannagan, R. (Ed.). (1998). The Riverside Milton. Boston: Houghton Mifflin Co.

Furman-Adams, W. \& Tufte V. J. (2004). Saying it with flowers: Jane Giraud's ecofeminist Paradise Lost. In C. G. Martin (Ed.), Milton and gender (p. 234, 235). Cambridge: Cambridge University Press.

Hiltner, K. (2003). Milton and ecology. Cambridge: Cambridge University Press.

Knott, J. R. (2005, June 13). Milton's wild garden. Studies in Philology. Retrieved from http://muse. jhu.edu/journals.

Mattison, A. (2007). Milton's uncertain Eden: Understanding place in Paradise Lost. In W. E. Cain (Ed.), Studies in Major Literary Authors (pp. 82, 96). New York: Routledge.

Miller, D. M. (1978). John Milton: Poetry. Boston: Twayne Publishers.

Nicolson, M. H. (1990). John Milton: A reader's guide to his poetry. NY: Octagon Books.

Strier, R. (2012). Milton's fretters, or, why Eden is better than heaven. In P. C. Herman \& E. Sauer (Eds.), The new Milton criticism (pp. 41, 42). New York: Cambridge University Press

Summers, J. H. (1966). The final vision. In L. L. Martz (Ed.), Milton-Paradise Lost: A collection of critical essays (p.189). Englewood Cliffs: Prentice Hall.

The Holy Bible. New International Version. (2011). Retrieved from http://biblegateway.com 